summer. The effect of the thermic utilization coefficient on the energy expenditure has been emphasized.

Approximate cost-price of the heating can be estimated according to measurements of the consumption per definite space of time. At present, other measurements in progress are going to complete these primary informations on energy expenditures expressed in therms per piggery (or per piglet) and on this basis an objective comparison of two different sources of energy will be possible.

\title{
SEVRAGE PRÉCOCE : RÉSULTATS OBTENUS SIMULTANÉMENT DANS UN TROUPEAU EXPÉRIMENTAL
}

\author{
Y. MAURY, M. PALISSE et F. POLINE \\ Éts Sanders \\ 17, Quai de l'Industrie, 91260 Juvisy sur Orge
}

\section{RÉSUMÉ}

Une comparaison entre des sevrages à $\mathbf{I} 7,22$ et 35 jours montre que le raccourcissement de la durée de lactation n'altère pas les performances de reproduction des truies en ce qui concerne la réussite des saillies et l'écart sevrage-saillie fécondante (respectivement Io, I4,5 et I5,2 jours).

Le raccourcissement de la durée de lactation augmente bien sûr le nombre de porcelets produits par an, 22,7, 2I,8 et 20 porcelets pour respectivement I 7, 22 et 35 jours de lactation.

La longévité des truies ne semble pas non plus être affectée par un sevrage à trois semaines.

\section{SUMMARY}

\section{EARLY WEANING : RESULTS IN AN EXPERIMENTAL HERD}

A comparison between weaning at 17,22 and 35 days shows that reduction of the lactation period does not alter reproduction performances of the sows with regard to fertility and time interval between weaning and fertilizing insemination (respectively ro days, I4,5 days and 15,2 days).

Obviously, reduction of the lactation period increases the number of piglets produced per year, 22,7-21,8 and 20 piglets when lactation lasted I 7,22 and 35 days respectively.

The longevity of the sows does not seem either to be affected by an early weaning at 3 weeks. 